\title{
PELATIHAN EFIKASI DIRI GURU: EFIKASI DIRI AKADEMIK DAN PRESTASI BELAJAR SISWA
}

\section{TEACHER SELF-EFFICACY TRAINING; ACADEMIC SELF-EFFICACY AND LEARNING ACHIEVEMENT OF STUDENTS}

\author{
Sowanya Ardi Prahara ${ }^{1}$, Kondang Budiyani ${ }^{2}$ \\ ${ }^{12}$ Universitas Mercu Buana Yogyakarta \\ 1sowanya_hara@yahoo.com, ${ }^{2}$ kondangpsi@yahoo.co.id
}

\begin{abstract}
Abstrak
Penelitian ini bertujuan untuk memperoleh bukti empiris mengenai efektivitas pelatihan strategi peningkatan efikasi diri pada guru mampu meningkatkan efikasi diri akademik dan prestasi belajar siswa. Hipotesis yang diajukan adalah ada perbedaan efikasi diri akademik siswa sebelum dan sesudah diberikan tritmen dan ada hubungan antara efikasi diri dengan prestasi belajar siswa. Subjek penelitian sebanyak 180 siswa. Design eksperimen yang digunakan adalah pretest-posttest control group design. Data dikumpulkan dengan menggunakan Skala Efikasi Diri Akademik. Hasil analisis data menggunakan paired sample t-test menunjukkan hasil nilai t sebesar 1.419 dengan taraf signifikansi 0.159 ( $\mathrm{p}<0.05)$. Hal ini menunjukkan tidak ada perbedaan efikasi diri akademik pada kelompok eksperimen sebelum dan sesudah diberikan perlakuan. Walaupun subjek memiliki efikasi diri akademik lebih tinggi setelah diberikan perlakuan dengan rerata sebesar 68.84 daripada sebelum diberikan perlakuan dengan rerata sebesr 67.89. Berdasarkan dari nilai rerata yang diperoleh dari pengukuran tersebut dapat diketahui bahwa perlakuan yang diberikan bukan berarti tidak berpengaruh terhadap subjek penelitian, melainkan disebabkan karena adanya variable extraneous yang turut serta di dalamnya. Selain itu, juga tidak ada hubungan antara efikasi diri akademik dengan prestasi belajar siswa.
\end{abstract}

Kata kunci: efikasi diri akademik, pelatihan efikasi diri, prestasi belajar, siswa

\begin{abstract}
This study aims to obtain empirical evidence regarding the effectiveness of training on self-efficacy improvement strategies in teachers whether or not it is able to improve academic self-efficacy and student achievement. The hypothesis proposed is that there are differences in students' academic self-efficacy before and after given the treatment and there is a relationship between self-efficacy and student achievement. The research subjects were 180 students. The experimental design used was the pretest-posttest control group design. Data is collected using the Academic Self-Efficacy Scale. The results of data analysis using paired sample $t$-test showed the results of $t$ values of 1.419 with a significance level of 0.159 ( $p<0.05)$. This shows that there is no difference in academic self-efficacy in the experimental group before and after treatment, even though the subject has a slightly higher academic self-efficacy after being given treatment with an average of 68.84 than before being treated with a mean of 67.89. Based on the average value obtained from these measurements, it does not mean that the treatment given has no effect to the research subject, but this is caused by the existence of extraneous variables that participate in it. In addition, there is also no relationship between academic self-efficacy and student achievement.
\end{abstract}

Keywords: academic self-efficacy, self-efficacy training, learning achievement, students

\section{PENDAHULUAN}

Pada masa globalisasi ini menuntut individu untuk selalu siap dalam menghadapi tantangan perubahan sosial. Oleh karena itu dibutuhkan kualitas individu yang mempunyai kriteria cerdas, memiliki kepercayaan diri yang tinggi, mandiri dan memiliki etos kerja 
yang baik (Suryanto, 2004). Hal ini menuntut individu agar mampu mencapai prestasi akademik yang baik dalam pendidikan, sehingga dapat menghasilkan lulusan yang berkualitas, memiliki kemampuan dalam keilmuan dan keimanan. Hal ini dikarenakan pendidikan merupakan faktor individu untuk mencapai kesiapan pada kapasistas dan kemauan individu untuk bersaing di kancah yang lebih luas (Carbery \& Garavan, 2005). Keberhasilan akademis siswa dipengaruhi terutama oleh kemampuan kognitifnya. Artinya, siswa dengan potensi intelektual yang tinggi akan lebih berhasil dibanding siswa yang memiliki kemampuan lintelektual lebih rendah. Namun, korelasi antara IQ dan prestasi biasanya hanya dalam kisaran sedang maka dapat dikatakan bahwa potensi kognitif tidak selalu berpengaruh pada pencapaian kesuksesan. Banyak individu yang berbakat secara intelektual yang tidak berprestasi dengan baik, tetapi ada banyak siswa dengan kemampuan kognitif lebih rendah justru memiliki prestasi yang lebih baik (Goleman, 2015). Banyak variabel terkait yang dapat digunakan untuk menjelaskan fenomena ini, namun perlu mempertimbangkan peran efikasi diri (self-efficacy) dalam prestasi akademik (Pajares \& Urdan, 2006). Bandura (dalam Pajares \& Urdan, 2006) mengungkapkan bahwa efikasi diri akademik siswa berkontribusi terhadap prestasi akademis melebihi dari kemampuan kognitifnya.

Bandura ( 1997) mengemukakan bahwa individu yang memiliki efikasi diri yang tinggi, akan berusaha lebih keras dalam mencapai prestasi, memiliki fleksibilitas tinggi dalam strategi pencarian solusi dan lebih akurat dalam evaluasi atas kualitas prestasi yang dicapai. Lebih lanjut dijelaskan bahwa efikasi diri berpengaruh positif terhadap seberapa banyak tekanan dan kesulitan-kesulitan yang dialami oleh siswa dalam mendapatkan prestasi akademik yang baik. Oleh karena itu dengan individu memiliki efikasi diri yang tinggi, maka akan mempengaruhi keyakinan individu akan kemampuannya dalam menggerakkan motivasi, kemampuan kognitifnya dan tindakan yang diperlukan untuk memenuhi tuntutan situasi (Bandura \& Woods, 1989). Hal ini dikuatkan juga oleh Kim dan Park (2006) yang menyebutkan bahwa efikasi diri sangat penting bagi pelajar untuk mengontrol motivasi dalam mencapai harapan-harapan akademik. Efikasi diri akademik jika disertai dengan tujuan-tujuan yang spesifik dan pemahaman mengenai prestasi akademik, maka akan menjadi penentu suksesnya perilaku akademik di masa yang akan datang (Bandura dalam Alwisol, 2009). Pemahaman ini menggambarkan bahwa efikasi diri akademik dapat menjadi suatu sumber daya yang sangat penting bagi pengembangan diri melalui pilihan aktivitas siswa (Schunk dalam Santrok, 2008). 
Namun kenyataannya berdasarkan hasil wawancara yang dilakukan kepada 8 siswa SD pada tanggal 5 Februari 2018 di sekolah, menunjukkan efikasi diri akademik siswa masih rendah. Hal ini ditunjukkan dengan adanya rasa ragu-ragu terhadap kemampuannya, sehingga mengurangi usahanya dalam mencapai tujuan atau tidak sedikit dari siswa yang malah menyerah. Selain itu terdapat keluahan-keluahan saat mengikuti pelajaran-pelajaran yang sulit, siswa juga kurang percaya pada dirinya, hal ini ditunjukkan ketika ulangan berlangsung tidak sedikit siswa yang masih mencontek pekerjaan temannya. Ketika mengerjakan tugas kelompok diserahkan pada teman yang dianggapnya bisa dan terdapat siswa yang mencontek bahkan tidak mengerjakan apabila diberikan pekerjaan rumah yang sulit. Hal ini menunjukkan siswa merasa dirinya tidak mampu, sehingga tidak menjalankan tanggung jawabnya untuk mengerjakan tugas-tugas yang diberikan. Berdasarkan hal tersebut, maka bisa disimpulkan bahwa terdapat indikasi rendahnya efikasi diri akademik pada siswa.

Efikasi diri merupakan keyakinan seseorang terhadap kemampuan atau kompetisinya untuk melakukan sebuah tugas, mencapai tujuan, atau mengatasi hambatan tertentu (Bandura, 2009). Pada siswa, efikasi diri menjadi penting karena keyakinan atas kemampuan yang dimiliki dalam menyelesaikan masalah dan mengatasi hambatan menjadi sangat diperlukan. Dalam hal ini, tidak hanya diperlukan potensi kognitif seperti intelegensi yang baik saja dalam menyelesaikan masalah-masalah dan mengatasi hambatan yang dihadapi para siswa tetapi juga dibutuhkan keyakinan diri berkaitan dengan kemampuan dan kesanggupan seorang pelajar untuk mencapai dan menyelesaikan tugastugas studi dengan target hasil dan waktu yang telah ditentukan (Bandura, 2009). Lebih lanjut dijelaskan bahwa efikasi diri akademik merupakan keyakinan seseorang terhadap kemampuan menyelesaikan tugas-tugas akademik yang didasarkan atas kesadaran diri tetang pentingnya pendidikan, nilai dan harapan pada hasil yang akan dicapai dalam kegiatan belajar. Sehingga efikasi diri dapat dipahami sebagai kekuatan bahwa seseorang mampu melakukan sesuatu yang diinginkan (Snyder \& Lopez, 2006).

Definisi tersebut merujuk pada individu yang mempunyai kapasitas dan digunakan untuk mendapatkan hasil atau pengaruh yang diinginkan. Selanjutnya dijelaskan lebih lanjut bahwa keyakinan siswa berada dalam dimensi academic work yang ebrkontribusi pada keyakinan diri akademik (Gafoor \& Ashraf, 2006). Adapun dimensi akademiknya (1) learning Process yang menggambaran proses belajar siswa; (2) Reading yang menggambarkan keterampilan membaca yang dimiliki oleh siswa; (3) Comprehension, menggambarkan tingkat pemahaman siswa dalam memaknai inti dari suatu materi; (4) 
Memory, menggambarkan kemampuan siswa dalam mengingat suatu materi; (5) Curricular Activities, yang menggambarkan aktivitas kurikuler siswa; (6) Time Management, yang menggambarkan kemampuan siswa dalam memanajemen waktu; (7) Teacher Student Relationship, menggambarkan hubungan antara siswa dengan guru; (8) Utilization of resources, menunjukkan efisiensi siswa dalam memanfaatkan sumber daya yang ada di sekitarnya; (9) Peer Relationship, menggambarkan hubungan antara siswa dengan teman sebaya; (10) Goal Orientation, yang menggambarkan orientasi siswa terhadap tujuan yang dimilikinya; (11) Adjustment, menggambarkan pengaturan diri terhadap situasi tertentu; (12) Examination, menggambarkan keyakinan siswa saat menghadapi ujian.

Bandura (2009) mengemukakan bahwa efikasi diri sangat berpengaruh pada bagaimana seseorang akan berperilaku. Semakin tinggi efikasi diri maka akan semakin baik performen/prestasinya. Orang yang efikasi diri rendah kemungkinan akan merasa apatis. Sebaliknya orang yang efikasi diri tinggi akan optimis. Berdasarkan hal ini maka peneliti berasumsi bahwa salah satu cara yang perlu diubah terkait mempersiapkan siswa untuk mendapatkan prestasi akademik yang baik adalah dengan meningkatkan efikasi diri akademik siswa. Dalam hal ini, guru merupakan salah satu pihak yang dapat meningkatkan efikasi diri akademik siswanya. Senada dengan penelitian yang dilakukan oleh Schunk (1984) yang menunjukkan bahwa guru dapat mempengaruhi siswa, sebagai upayanya menerangkan pengalaman kegagalan dan pengalaman keberhasilan yang lebih efektif terhadap performance siswa saat belajar, dengan demikian guru diharapkan dapat mempengaruhi efikasi diri akademik siswa. Efikasi diri seseorang menurut Bandura (2009) dipengaruhi oleh beberapa faktor. Dijelaskan lebih lanjut, faktor-faktor yang mempengaruhi efikasi diri seseorang tersebut yang pertama adalah pengalaman keberhasilan (mastery experience), pengalaman orang lain (vicarious experience), persuasi sosial (social persuation), serta keadaan fisiologis dan emosional (physiological and emotional states) seseorang.

Factor-faktor yang disebutkan oleh Bandura (2009) tersebur dapat meningkatkan self-efficacy seseorang, di mana sebelum seseorang melakukan atau memunculkan perilaku tertentu dibutuhkan aspek kepercayaan diri akan kemampuan yang dimiliki, atau disebut sebagai self-efficacy. Efikasi diri merupakan kepercayaan diri yang dimiliki individu. dengan memiliki efikasi diri yang tinggi, maka seseorang akan mampu menghasilkan sesuatu dengan lebih baik. Keyakinan dalam diri menentukan bagaimana orang merasa, berfikir memotivasi diri dan berperilaku. Begitu juga efikasi diri akademik siswa, dengan 
guru memberikan pengalaman keberhasilan dan kegagalan dama proses belajar, maka diharapkan siswa memiliki efikasi diri akademik yang lebih baik.

Salah satu upaya meningkatkan efikasi diri akademik adalah melalui pelatihan (Sdorow, 1990). Pelatihan menurut Ancok (2002) adalah suatu metode untuk membiasakan diri, hal ini dikarenakan pelatihan menggunakan simulasi-simulasi kehidupan sehari-hari, adanya pembelajaran berdasarkan pengalaman dan menggunakan permainan-permainan yang menyenangkan. Dengan diberikannya pelatihan strategi peningkatan efikasi diri akademik pada guru, selanjutnya guru dapat menerapkannya pada para siswa. Sehingga diharapkan keyakinan diri akademik para siswa meningkat terhadap kemampuan dalam melakukan sebuah tugas, mencapai tujuan, serta dalam mengatasi hambatan-hambatan dalam meraih prestasi akademiknya sehingga prestasi akademiknya akan meningkat.

Rumusan masalah yang diajukan adalah apakah ada pengaruh pelatihan efikasi diri pada guru dapat meningkatkan efikasi diri akademik dan prestasi belajar siswa?

\section{Hipotesis}

Ada peningkatan efikasi diri akademik siswa kelompok eksperimen sebelum dan setelah pemberian pelatihan.

Ada hubungan antara efikasi diri akademik dengan prestasi belajar siswa.

\section{METODE}

Subjek dalam penelitian ini adalah guru dan siswa sekolah dasar Muhammadiyah Suronatan berjumlah 180 siswa kelas 4,5 dan 6. Kelas 4A, 5A dan 6A, peneliti memutuskan memilih kelas A sebagai kelompok eksperimen, dan kelas 4B, 5B dan 6B sebagai kelompok kontrol. Hal ini dilakukan karena, otoritas dari institusi yang telah menentukan kelas mana saja yang akan menjadi kelompok eksperimen dan kelompok control. Sehingga, peneliti tidak dapat melakukan random saat menentukan kelompok penelitian.

Alat pengumpul data yang digunakan dalam penelitian ini adalah Academic SelfEfficacy Scale yang akan digunakan untuk mengungkap academic self-efficacy para siswa berdasarkan Teori Self-Efficacy dari Bandura (1997) dalam framework Teori Kognitif Sosial. Skala ini didasarkan pada pemahaman bahwa keyakinan siswa berada dalam dimensi academic work yang akan berkontribusi pada academic self-efficacy (Gafoor \& Ashraf, 2006). Adapun dimensi akademiknya (1) learning Process yang menggambaran proses belajar siswa; (2) Reading yang menggambarkan keterampilan membaca yang 
dimiliki oleh siswa; (3) Comprehension, menggambarkan tingkat pemahaman siswa dalam memaknai inti dari suatu materi; (4) Memory, menggambarkan kemampuan siswa dalam mengingat suatu materi; (5) Curricular Activities, yang menggambarkan aktivitas kurikuler siswa; (6) Time Management, yang menggambarkan kemampuan siswa dalam memanajemen waktu; (7) Teacher Student Relationship, menggambarkan hubungan antara siswa dengan guru; (8) Utilization of resources, menunjukkan efisiensi siswa dalam memanfaatkan sumber daya yang ada di sekitarnya; (9) Peer Relationship, menggambarkan hubungan antara siswa dengan teman sebaya; (10) Goal Orientation, yang menggambarkan orientasi siswa terhadap tujuan yang dimilikinya; (11) Adjustment, menggambarkan pengaturan diri terhadap situasi tertentu; (12) Examination, menggambarkan keyakinan siswa saat menghadapi ujian.

Academic Self-Efficacy Scale berisi pernyataan yang terdiri dari 21 aitem. Masingmasing pernyataan terdiri dari 4 alternatif jawaban yaitu sangat sesuai (SS), sesuai (S), tidak sesuai (TS) dan sangat tidak sesuai (STS). Pemberian penilaian adalah sebagai berikut sangat sesuai (SS) dinilai 4, sesuai (S) dinilai 3, tidak sesuai (TS) dinilai 2 dan sangat tidak sesuai (STS) dinilai 1. Skor tinggi yang diperoleh menunjukkan efikasi diri akademik yang tinggi, sebaliknya skor rendah yang diperoleh menunjukkan efikasi diri akademik yang rendah. Hasil uji coba yang dilakukan pada siswa, menunjukkan koefisien daya beda aitem bergerak 0,265-0,532. Peneliti menggunkan batas kriteria koefisien korelasi minimal 0,25 (Azwar, 2016). Aitem Academic Self-Efficacy Scale gugur 3 aitem, yaitu aitem nomer 3, 7 dan 9. Sehingga jumlah aitem Academic Self-Efficacy Scale berjumlah 21 aitem.

Pelatihan efikasi diri disusun berdasarkan teori Bandura (1997), yaitu vicarious experience, mastery experience, physiological state, dan verbal persuation. Metode yang digunakan adalah dengan ceramah, penayangan film, diskusi dan permainan. Sebelum digunakan, modul pelatihan efikasi diri dipastikan dengan melalui profesional judgement oleh dosen dan praktisi psikologi, Reny Yuniasanti, M.Psi., Psikolog (Ph.D. candidate). Hasil dari profesional judgement, modul diminta untuk melengkapi penjelasan kegiatan di bagian lampiran, selebihnya modul bisa digunakan sebagai pedoman pelatihan.

Rancangan kuasi eksperimen yang digunakan adalah pretest-posttest control group design.

\begin{tabular}{cc}
\hline KE & ED1 X ED2 \\
KK & ED1 - ED2 \\
\hline
\end{tabular}

Gb. 1 Rancangan eksperimen 
Keterangan:

ED1 : Pengukuran efikasi diri (pre test)

ED2 : Pengukuran efikasi diri (post test)

$\mathrm{X}$ : Perlakuan yaitu Pelatihan efikasi diri akademik pada guru

- : Tidak mendapat perlakuan

Analisis data menggunakan paired sample t-test, independent sample t-test dan korelasi bivariat.

\section{HASIL DAN PEMBAHASAN}

Berdasarkan hasil analisis dengan menggunakan independent sample t-test diperoleh nilai t sebesar -1.564 dengan taraf signifikansi sebesar $0.120(\mathrm{p}<0.05)$ dan hasil dari uji hipotesis melalui paired sample t-test diperoleh nilai t sebesar 1.419 dengan taraf signifikansi sebesar $0.159(\mathrm{p}=<0.05)$. Hal ini menunjukkan tidak adanya perbedaan rerata skor efikasi diri akademik antara kelompok eksperimen sebelum dan sesudah diberikan perlakuan. Berdasarkan hasil analisis data tersebut menunjukkan bahwa hipotesis dinyatakan tidak diterima. Walaupun begitu subjek memiliki efikasi diri akademik lebih tinggi setelah diberikan perlakuan dengan rerata sebesar 68.84 daripada sebelum diberikan perlakuan dengan rerata sebesr 67.89. Berdasarkan dari nilai rerata yang diperoleh dari pengukuran tersebut dapat diketahui bahwa bukan berarti perlakuan yang diberikan tidak berpengaruh terhadap subjek penelitian, melainkan disebabkan karena adanya variable extraneous yang turut serta di dalamnya.

Variable extraneous adalah variabel-variabel atau faktor-faktor yang dapat mengancam validitas internal dalam eksperimen (Azwar, 2016). Lebih lanjut dijelaskan bahwa validitas internal adalah sejauh mana perubahan yang terjadi pada variabel tergantung benar-benar disebabkan oleh perlakuan yang diberikan, bukan disebabkan oleh faktor-faktor kebetulan atau lainnya yang tidak relevan. Hal inilah yang kemungkinan menyebabkan perlakuan yang diberikan tidak memperlihatkan hasil yang signifikan. Hal ini ditunjukkan dari hasil analisis data terjadi peningkatan mean kelompok eksperimen sebelum dan sesudah diberikan perlakuan, walaupun peningkatan tersebut tidak signifikan.

Adapaun variabel extraneous pertama yang berpengaruh adalah tidak dilakukannya random pada subjek penelitian dalam menentukan kelompok eksperimen dan kelompok kontrol. Hal ini dikarenakan otoritas dari institusi yang telah menentukan kelas mana saja yang menjadi kelompok eksperimen dan kelas mana saja yang akan menjadi kelompok kontrol. Peneliti tidak dapat melakukan random pada saat pemilihan kelompok eksperimen 
dan kelompok kontrol. Selanjutnya, peneliti harus menentukan kelas 4A, 5A dan 6A sebagai kelompok eksperimen dan kelas 4B, 5B dan 6B sebagai kelompok kontrol. Dari awal rerata data pretest kelompok kontrol yang diperoleh lebih tinggi dibandingkan dengan rerata data pretest kelompok eksperimen. Menurut Myers dan Hansen (2012) ancaman seleksi dapat mengakibatkan perubahan yang diukur setelah diberikan perlakuan ternyata bukan dikarenakan perbedaan perlakuan yang diberikan, melainkan karena subjek penelitian memiliki karakter yang berbeda. Hal inilah yang menyebabkan efektivitas perlakuan yang diberikan tidak menunjukkan perubahan yang signifikan.

Kedua kurangnya kontrol pada saat pengerjaan yang dilakukan oleh siswa. Hal ini dikarenakan terlalu banyak siswa yang ada di kelas, sehingga asisten peneliti tidak mampu untuk mengontrol prilaku subjek penelitian satu persatu. Terdapat indikasi subjek saling melihat pekerjaan teman yang lainnya dan juga melakukan faking good terhadap respon yang diberikan terhadap alat ukur. Hal ini dapat dilihat dari hasil wawancara awal yang menunjukkan bahwa subjek merasa belum yakin apabila dihadapkan dengan ujian, selain itu subjek juga mengeluh tidak mampu menyelesaikan soal yang diberikan apabila tugas yang diberikan lebih sulit dari soal sebelumnya, hal ini juga mempengaruhi perilaku subjek yang tidak terlalu antusias ketika diminta untuk menjawab pertanyaan guru yang diberikan. Perilaku faking good inilah yang menyebabkan skor efikasi diri akademik siswanya cenderung bergerak ke arah tinggi.

Ketiga, Pelatihan efikasi diri pada guru diberikan sekali. Setelah pelatihan selesai, guru diminta untuk menerapkannya pada kegiatan belajar mengajar di kelas. Namun pada prakteknya guru yang mendapatkan pelatihan efikasi diri tidak menerapkan pengetahuan dan ketrampilannya untuk meningkatkan efikasi diri akademik kepada para siswanya. Walaupun, berdasarkan hasil self-monitoring yang dibuat oleh guru, guru menuliskan bahwa materi pelatihan yang diterima sudah diterapkan dengan baik. Materi pelatihan seperti ice breaking, memberikan pujian, memberikan soal yang bergradasi tingkat kesulitannya, menunjuk siswa yang mampu untuk mengerjakan di depan sampai bernyanyi bersama sudah dilakukan. Namun, hal ini berbeda dengan hasil observasi dan monitoring yang dilakukan oleh asisten penelitian di kelas-kelas kelompok eksperimen. Guru terlihat tidak menerapkan materi pelatihan secara kontinyu di setiap pengajarannya. Guru hanya memberikan satu atau dua hal saja di setiap pengajaran, bahkan ada guru yang tidak melakukan sama sekali. Hal ini juga dikuatkan oleh signifikan other di sekolah yang menyatakan bahwa guru-guru belum dapat menerapkan materi pelatihan secara kontinyu karena beban mengajar yang penuh, yang menuntut guru untuk dapat membahas habis 
capaian materi yang telah ditetapkan sebelumnya dalam waktu sehari, seminggu, sebulan dan satu semesternya. Guru tidak memiliki cukup waktu untuk menerapkan materi pelatihan di setiap pengajarannya. Hal inilah yang akhirnya menyebabkan materi pelatihan tidak dapat diterapkan dengan baik di setiap pengajarannya di dalam kelas. Dengan tidak diterapkannya materi pelatihan dengan baik dan kontinyu, maka materi tersebut tidak dapat tersampaikan ke dalam kelas dan para siswanya. Sehingga pengaruh dari pelatihan yang diberikan tidak memiliki efek yang besar, bahkan tidak berpengaruh. Hal ini senada yang dikemukakan oleh Seligman (2009) bahwa apabila materi tidak disampaikan dengan baik, maka pengaruh dari pelatihan tersebut juga tidak menunjukkan hasil yang baik.

Selanjutnya berdasarkan hasil analisis korelasi bivariate dengan tujuan untuk mengetahui hubungan antara efikasi diri akademik dengan prestasi belajar. Hasil uji korelasi bivariate diperoleh $\mathrm{r}$ sebesar 0.098 dengan taraf signifikansi sebesar 0.192 $(\mathrm{p}<0.05)$. Hal ini menunjukkan tidak ada hubungan antara efikasi diri akademik dengan prestasi belajar pada siswa. Tidak adanya hubungan di atara kedua variabel ini dimungkinkan karena disebabkan pengaruh dari faktor-faktor lain terhadap prestasi belajar. Dikuatkan dengan skor sumbangan efektif dari variabel efikasi diri akademik pada prestasi belajar yang sangat kecil yaitu hanya berada pada $1 \%$ saja. Artinya efikasi diri akademik hanya memberikan sumbangan 1\% terhadap prestasi belajar siswa, dan 99\% lainnya disebabkan oleh faktor-faktor yang lain.

Menurut Slameto (2010) faktor yang mempengaruhi prestasi belajar siswa digolongkan menjadi dua golongan besar. Faktor tersebut adalah faktor interen dan juga faktor ekstern. Kaktor ekstern adalah faktor yang ada di luar individu, yang meliputi faktor keluarga, sekolah, dan masyarakat. faktor intern adalah faktor yang ada dalam diri individu yang sedang belajar, yaitu meliputi kesehatan jasmani, cacat tubuh, intelegensi, perhatian, minat, bakat, motivasi belajar, kesiapan, sikap siswa dan kelelahan. Kemungkinan besar faktor-faktor yang lain ini lah yang berpengaruh terhadap skor prestasi belajar siswa.

\section{KESIMPULAN}

Berdasarkan analisis data tersebut dapat disimpulkan bahwa hipotesis dalam penelitian ini tidak diterima. Walaupun begitu subjek memiliki efikasi diri akademik lebih tinggi setelah diberikan perlakuan dengan rerata sebesar 68.84 daripada sebelum diberikan perlakuan dengan rerata sebesr 67.89. Berdasarkan dari nilai rerata yang diperoleh dari pengukuran tersebut dapat diketahui bahwa bukan berarti perlakuan yang diberikan tidak 
berpengaruh terhadap subjek penelitian, melainkan disebabkan karena adanya variable extraneous yang turut serta di dalamnya.

\section{SARAN}

\section{Bagi Guru}

Guru hendaknya mempraktekkan ketrampilan dan pengetahuannya dalam kegiatan belajar mengajar di kelas setiap harinya guna meningkatkan efikasi diri akademik siswa.

\section{Bagi Peneliti Selanjutnya}

Bagi peneliti selanjutnya yang tertarik dengan penelitian serupa, disarankan dapat melakukan random terhadap subjek penelitiannya. Selain itu, peneliti selanjutnya harus memperhatikan lebih lanjut pada variable ekstrane yang perlu dikontrol. Penelti selanjutnya perlu untuk mengukur pengetahuan dan kemampuan efiksi diri guru. Peneliti selanjutnya juga perlu menambah jumlah pelatihannya, supaya para guru lebih memahami dan menguasai materinya.

\section{DAFTAR PUSTAKA}

Alwisol. (2009). Psikologi kepribadian. Malang: UMM Press.

Ancok. (2002). Outbond management training. Yogyakarta: UII Perss.

Azwar, S. (2016). Reliabilitas dan validitas (edisi 4). Yogyakarta: Pustaka Pelajar.

Azwar, S. (1996). Pengantar tes inteligensi. Yogyakarta: Pustaka Pelajar.

Bandura, A. (1997). Self-efficacy: the exercise of control. New York: W.H. Freeman and Company.

Bandura, A. (2009). Efikasi diriin changing societies. New York: Cambradge University Press.

Bandura, A., \& Wood, RE. (2009). Effect of percieved control ability and performance standarts on self-regulation of complex decision-making. Journal of Prsonality and Social Psychology, 56, 805-814

Carbery, R., \& Garavan, T. N. (2004). Who learns at work? Who are the employees with learning opportunities?. Paper presented at the Fifth Annual UFHRD/AHRD Conference, University of Limerick, 27th-28th May.

Gafoor, A.K., \& Ashraf, M.P. (2006). Academic self-efficacy scale. Calicut: University of Calicut, Department of Education.

Goleman, D. (2015). Kecerdasan emosional: Mengapa ei lebih penting daripada iq. Jakarta: Gramedia Pustaka Utama. 
Kim, U., \& Park, Y. S. (2006). Factors influencing academic achievement in relational cultures: The role of self, relational and collective efficacy. In: F. Pajares \& T. Urdan, eds. Self-efficacy beliefs of adolescents, pp. 267-285. Greenwich, CT: Information Age Publishing.

Myers, A., \& Hansen, C. (2012). Experimental psychology (seventh edition). USA: Wadsworth.

Santrock, J.W. (2008). Life-span development: perkembangan masa hidup. Jakarta:Arlangga

Schunk, D.H. (1984). Efikasi diriperspective on achievement behavior. Educational Psychologist, 19, 48-58.

Seligman, M.E.P. (2008). Menginstal optimisme. Bandung : Momentum.

Snyder, C.R., \& S. J. Lopez. (2006). Handbook of Positive Psychology. New York: Oxford University Press.

Sdorow, L. (1990). Psychology. New York: WM. C. Brown Publishers.

Slameto. (2010). Belajar dan faktor-faktor yang mempengaruhinya (edisi revisi). Jakarta: PT. Rineka Cipta.

Suryanto, M. (2004). Motivasi kepemimpinan. Jakarta: Rineka Cipta. 